\title{
Comparative studies of biological activity of cadmium-based quantum dots with different surface modifications
}

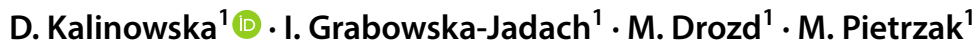

Received: 7 August 2017 / Accepted: 19 April 2018 / Published online: 4 May 2018

(c) The Author(s) 2018

\begin{abstract}
This paper presents a modification of the surface of $\mathrm{CdS} / \mathrm{ZnS}$ and $\mathrm{CdSe}_{x} \mathrm{~S}_{1-x} / \mathrm{ZnS}$ quantum dots (QDs) with 3-mercaptopropionic and 6-mercaptohexanoic acid. The obtained QDs were characterized using TEM, DLS, UV-Vis, and fluorescence spectroscopy. Flow cytometry was applied to evaluate the cytotoxicity of QDs and examine the type of death caused by the tested nanoparticles. In addition, the generation of reactive oxygen species after incubation of the tested cells with $\mathrm{CdSe}_{x} \mathrm{~S}_{1-x} /$ $\mathrm{ZnS}-\mathrm{MPA}$ and $\mathrm{CdSe}_{x} \mathrm{~S}_{1-x} / \mathrm{ZnS}-\mathrm{MHA}$ QDs was evaluated. The study was conducted on three cell lines: adherent (A549 and MRC-5) and suspension ones (K562). The conducted research demonstrated that the tested nanoparticles exhibit concentration-dependent toxicity. It was observed that the surface modification influences the toxicity level of the examined QDs, and modification of their surface with the use of the ligand of longer carbon chain (MHA) reduces the toxicity in comparison with QDs-MPA. It was also found that all tested QDs caused the death of cells in the course of necrosis. Based on obtained results, it was concluded that the cytotoxicity of QDs is to a large extent related to reactive oxygen species (ROS) generation.
\end{abstract}

Keywords Quantum dots $\cdot$ Nanoparticles $\cdot$ Toxicity $\cdot$ Apoptosis $\cdot$ Necrosis $\cdot$ Reactive oxygen species

\section{Introduction}

Quantum dots (QDs) are non-organic fluorescent semiconductor nanocrystals, which usually consist of a core and a shell. The core of QDs is composed of chemical elements from groups II-VI, III-V, or IV-VI, for example, CdSe, InAs, or PbTe (Casas et al. 2014, Pu et al. 2018). The core may be covered with a shell, which enhances optical properties of QDs, reduces the release of chemical elements from the core, and protects it from oxidation (Medintz et al. 2005; Subila et al. 2013).

QDs possess preferable optical properties in comparison with organic fluorophores. These include more intensive and stable fluorescence, narrow, and symmetric emission peaks and broad absorption spectra (Huy et al. 2018; Zhou et al. 2015). One of the advantages of QDs is a possibility to conjugate a large number of different substances including peptides, aptamers, or antibodies to their surface (Chandan et al. 2018). It can influence on the QD-conjugated cellular

D. Kalinowska

dkalinowska@ch.pw.edu.pl

1 Faculty of Chemistry, Warsaw University of Technology, Noakowskiego 3, 00-664 Warsaw, Poland localization (after their introduction to the organism) and their binding affinity (Karakoti et al. 2015). QDs find many applications in biological sciences for fluorescent labeling of cells and their intracellular compartments (organelles), and as labeling compounds (proteins and nucleic acids) in living and fixed cells (Bagher 2016; Mal at al. 2016). Due to the intensive fluorescence of QDs, they may be used in medical diagnostics for determination of certain diseases, including infectious bacterial and viral ones, as well as for detection and localization of cancer cells (Kim et al. 2018; Tram et al. 2016; Vasudevan et al. 2015). Besides, polymeric (Niu et al. 2017) gold nanoparticle-based drug carriers (Farooq et al. 2018; Ramalingam et al. 2018) were reported to be used in medicines delivery (Javanbakht and Namazi 2018; RanjbarNavazi et al. 2018). The long-term monitoring of different processes in vitro and in vivo is also possible due to the stability of their fluorescence (Michalet et al. 2005; Ni et al. 2018; Vu et al. 2015).

Cadmium-based QDs were the first commercially available and it should be pointed out that they are characterized with high quantum yield and a good stability. Moreover, the efficient synthesis routes and various surface modification methods of such QDs were extensively described (Soenen et al. 2014; Xu et al. 2016). Nonetheless, some 
studies showed that cadmium may be released from the core of QDs to the solution, and as a result, toxicity of these nanoparticles may be observed (Chen et al. 2012; Rocha et al. 2016). The toxicity of QDs can be dependent on many parameters such as composition, size, surface modifications, and concentration (Bruneau et al. 2015). Therefore, there is a strong need to better understand the relationship between the composition of QDs (composition of both core and shell, and a kind of surface ligands) and their influence on the living cells.

There have been many methods described for the evaluation of biological activity of the chemical substances. One of them is flow cytometry. Flow cytometry is a technique that uses scattered light and fluorescence measurements for a quantitative multiparameter analysis of single cell under flow conditions (Adan et al. 2016). The main advantage of flow cytometry over other types of viability tests (e.g., one of the most commonly used MTT test) is that flow cytometry provides information about a large number (usually about 10,000) of single cells instead of average signal from the whole cell population. Flow cytometry usage ensures that subtle but important differences occurring between individual cells will not be overlooked. This technique has been commonly used for an evaluation of nanomaterials influence on cells in vitro, especially for studies regarding a cellular uptake of nanoparticles (Fan et al. 2015; Fernández et al. 2015; Kim et al. 2016; Manshian et al. 2015; Tabei et al. 2015). When using the flow cytometry, there is also possible to examine the toxicity of QDs and determine the type of cell death caused by these nanoparticles (He et al. 2016; Lai et al. 2015; Yan et al. 2016).

The apoptosis and necrosis are the main types of cell death. Apoptosis is a physiological process of programmed cell death, which is essential to provide the homeostasis in organisms. Apoptotic cells decrease their volume while preserving the membrane integrity. On the other hand, during necrosis, the cells increase their volume until they release their content into extracellular space, which usually leads to inflammation (Nikoletopoulou et al. 2013; Rello-Varona et al. 2015). Therefore, the knowledge of the type of cells' death after the exposure to the tested compounds is essential to estimate their influence on a human organism and such information can determine the future applications of QDs. Substances that cause apoptosis are often used as drugs in anticancer treatment due to the nature of this process, which causes no inflammatory response in comparison with necrosis (Hassan et al. 2014; Yang et al. 2017; Wesselborg et al. 1999).

There are few ways of QDs penetration into a human body. These approaches include inhalation, oral digestion, and skin application (Yildirimer et al. 2011). The same QDs may lead to the occurrence of different reactions in vivo, depending on the way of penetration. For example, the inhalation primarily influences lung cells while not damaging other organs.

In this manuscript, we described the research on the cytotoxicity of core/shell CdSe/ZnS and $\mathrm{CdSe}_{x} \mathrm{~S}_{1-x} / \mathrm{ZnS}$ quantum dots modified with two different surface ligands: 3-mercaptopropionic acid (MPA) and 6-mercaptohexanoic acid (MHA). Our study was conducted on K562 cell line, which was used as a model of blood cells, and on two lung cell lines A549 and MRC-5 to understand the possible influence of QDs on a human organism. We also determined a type of death caused these nanomaterials and checked whether their cytotoxicity is related to an appearance of reactive oxygen species (ROS).

\section{Experimental work}

\section{Materials}

Core-shell-type CdSe/ZnS QDs (core diameter of $3.7 \mathrm{~nm}$ and maximum of fluorescence emission at $530 \mathrm{~nm}$ ) coated with hydrophobic ligands were purchased as a powder from PlasmaChem (Germany). CdSe $\mathrm{S}_{1-\lambda} / \mathrm{ZnS}$ core-shell QDs (core diameter of $6 \mathrm{~nm}$ and maximum of fluorescence emission at $490 \mathrm{~nm}$ ) stabilized with oleic acid were purchased as a solution in toluene from Sigma-Aldrich. 3-mercaptopropionic acid (MPA), 6-mercaptohexanoic acid (MHA), tetramethylammonium hydroxide pentahydrate (TMAH), cadmium nitrate, mercury(II) nitrate, sodium hydroxide, and sodium dihydrogen phosphate were purchased from Sigma-Aldrich. Anhydrous ethanol, chloroform, sodium chloride, nitric acid (65\%), and acetic acid (99.5\%) were purchased from Avantor (formerly POCH), Poland. All reagents were used as received. Dialysis tubing cellulose membrane $(\mathrm{MWCO}=2000 \mathrm{Da})$ was purchased from Sigma-Aldrich.

Cell lines: A549 (human lung epithelial carcinoma), MRC-5 (normal human lung fibroblasts), and K562 (human lymphoblast bone marrow) were obtained from The European Collection of Cell Cultures. For cell culturing, the following materials and reagents were used: tissue culture flasks for adherent and for suspension cells (Sarstedt), Minimum Essential Medium Eagle (MEME, Sigma-Aldrich), RPMI-1640 (Sigma-Aldrich), fetal bovine serum (FBS, Life Technologies), L-glutamine (200 mM, Sigma-Aldrich), penicillin-streptomycin (10,000 units penicillin, $10 \mathrm{mg}$ streptomycin/ml, Sigma-Aldrich), MEM non-essential amino acid solution (Sigma-Aldrich), phosphate buffered saline (PBS, Sigma-Aldrich), Tryple Express (Life Technologies), trypan blue solution (0.4\%, Sigma-Aldrich), fast read disposable counting slides (Immune Systems), 12-well plates (Sarstedt), annexin V-FITC/PI apoptosis/ necrosis detection kit (BD Pharmigen), 2',7'-dichlorofluorescein (Sigma-Aldrich), dimethyl sulfoxide $(\mathrm{POCH}), 5 \mathrm{ml}$ 
polypropylene round-bottom tube for flow cytometry (BD Falcon). The equipment used in this study were as follows: JEOL JEM1200EX STEM electron microscope, Malvern Zetasizer Nano ZS90, Perkin-Elmer Lambda 25 spectrophotometer, Cary Eclipse fluorescence spectrophotometer (Varian, USA), CHI660A electrochemical workstation (CHInstruments, USA), OLYMPUS CKX41 optical microscope, BioTek microplate reader, BD FACS Calibur flow cytometer, Hettich Zentrifugen Universal 320R centrifuge.

\section{Methods}

\section{Ligand exchange}

All solutions of QDs were solubilized in water with the use of biphasic phase transfer protocol, based on the previously described procedures for thiolated ligands (GrabowskaJadach et al. 2016b; Liu et al. 2007; Tamang et al. 2011). $\mathrm{CdSe}_{x} \mathrm{~S}_{1-x} / \mathrm{ZnS}$ coreshell QDs solution in toluene was centrifuged with the fourfold aliquot of anhydrous ethanol (RCF $18,187 \times g, 15 \mathrm{~min}$ ) and the pellet was resuspended in chloroform prior to ligand exchange. In general, $100 \mathrm{mM}$ aqueous solution of MPA or MHA $(800 \mu \mathrm{L})$ of $\mathrm{pH}$ adjusted to 11.0 by means of TMAH was added to the solution of QDs in chloroform $(800 \mu \mathrm{L})$ and vigorously shaken for $4 \mathrm{~h}$ in darkness. The aqueous phase containing QDs was isolated and colorless organic phase was discarded. The QDs were centrifuged (RCF $15,000 \times g, 15 \mathrm{~min}$ ) to remove larger aggregates and supernatant was dialyzed repeatedly for $8 \mathrm{~h}$ against $10 \mathrm{mM}$ phosphate buffered saline ( $\mathrm{pH}$ 7.4) in dark, sealed bottle. Efficient purification of QDs from both chemicals used for phase transfer and excess of ligands was additionally confirmed by monitoring of $\mathrm{pH}$ and the use of Ellman's assay for free thiols determination (Ellman 1959). Before optical characterization or biological applications, the QDs solutions were filtered with syringe filters made of regenerated cellulose (pore size $0.22 \mu \mathrm{m}$ ) and then stored at $4{ }^{\circ} \mathrm{C}$.

\section{Characterization of quantum dots}

The semiconductor core/shell and the hydrodynamic diameters of QDs after ligand exchange were measured by means of transmission electron microscopy and dynamic light scattering, respectively. TEM micrographs were captured using JEOL JEM-1200EX STEM electron microscope at an accelerating voltage of $30 \mathrm{kV}$. Dynamic light scattering data was obtained using Malvern Zetasizer Nano ZS90 (all samples in pH 7.4 PBS buffer). Long-term stability of QDs was monitored analyzing UV-Vis spectra. Absorption spectra were obtained with Perkin-Elmer Lambda 25 spectrophotometer with a slit width of $1.0 \mathrm{~nm}$. Photoluminescence spectra were acquired using Cary Eclipse fluorescence spectrophotometer
(Varian, USA), with $400 \mathrm{~nm}$ excitation and $1.0 \mathrm{~nm}$ slit width for excitation and emission.

\section{Determination of $\mathrm{Cd}^{2+}$ ions' concentration}

The cadmium ions concentration in QDs was determined using voltammetry. It enabled to compare the biological activity of four different types of QDs containing the same amount of $\mathrm{Cd}^{2+}$ ions. Voltammetric measurements were conducted using CHI660A electrochemical workstation (CHInstruments, USA) and the three-electrode system. The determination of cadmium released from acid-dissolved QDs samples was carried out using differential pulse anodic stripping voltammetry (DPASV). The detailed description of measurement parameters can be found in our previous work (Grabowska-Jadach et al. 2016a). In brief: acetate buffer, $0.2 \mathrm{M}, \mathrm{pH} 4.6$, containing $50 \mu \mathrm{M}$ of mercury(II) nitrate was used as a supporting electrolyte. Electrochemical studies were performed in deaerated samples, under argon atmosphere. Before the measurements, QDs sample was dissolved in $5 \mathrm{M}$ nitric acid. A method of multiple standard additions (additive of $50 \mu \mathrm{L}$ acid-digested QD followed by fourfold standard solution of $100 \mu \mathrm{M}$ cadmium nitrate (each of $50 \mu \mathrm{L})$ ) was applied. The determination was repeated three times for each sample and then the average value of $C_{\mathrm{Cd}^{2+}}$ in all types of QDs was calculated. Before incubation with cell lines, QDs were diluted with serum-free culture medium to obtain desired QDs concentration.

\section{Cell culturing}

K562 cells were cultured in RPMI-1640 supplemented with $10 \%$ FBS, 1\% penicillin-streptomycin and 1\% L-glutamine. A549 and MRC-5 cells were cultured in MEME supplemented with $10 \%$ FBS, $1 \%$ L-glutamine and $1 \%$ penicillin-streptomycin. Medium for MRC-5 cells was additionally supplemented with $1 \%$ MEM non-essential amino acid solution. The cells were incubated at $37{ }^{\circ} \mathrm{C}$ in $5 \% \mathrm{CO}_{2}$ atmosphere. The cells cultures were passaged three times a week.

\section{Cytotoxicity of QDs}

The K562 cell line was cultured in a culture flask. For the cytotoxicity tests, cells were centrifuged and suspended in serum-free medium (containing RPMI-1640, penicillin-streptomycin and L-glutamine). The density of the cells was evaluated using trypan blue staining and counting slides. Trypan blue is a dye, which stains only dead cells and, therefore, enables determination of the viability of cells (AvelarFreitas et al. 2014). The study was conducted when the viability of the cells was above $90 \%$. $500 \mu \mathrm{l}$ of cell suspension was added to 12 -well plates at a density of $2 \times 10^{5}$ cells per well. Then QDs solutions in the same medium were prepared

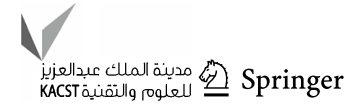


and introduced to wells with cells cultures in the amount of $500 \mu$, so that the final concentrations of QDs (expressed as $\mathrm{Cd}^{2+}$ concentration) in wells were: $0 \mu \mathrm{M}-$ control, 5,25 , 50,75 and $100 \mu \mathrm{M}$. The cells were incubated for $24 \mathrm{~h}$ at $37{ }^{\circ} \mathrm{C}$ in $5 \% \mathrm{CO}_{2}$. Afterwards, the contents of the wells were transferred to $5 \mathrm{ml}$ flow cytometry tubes and centrifuged (RCF $380 \times g, 3 \mathrm{~min}$ ).

To evaluate the cytotoxicity of the QDs, the following procedure was applied for A549 and MRC-5 cell lines. The cells from culture flasks were washed with PBS. Then Tryple Express was added to the culture flasks and incubated for 3-5 min to allow cell detachment. The cells were centrifuged (RCF $380 \times g, 3 \mathrm{~min}$ ) and suspended in $1 \mathrm{ml}$ of growth medium. The cells were stained with trypan blue and counted using counting slides. The cells were seeded into 12 -well plates at a density of $2 \times 10^{5}$ cells per well and incubated at $37^{\circ} \mathrm{C}$ in $5 \% \mathrm{CO}_{2}$ atmosphere overnight to allow cell adhesion. Then the growth medium was replaced with $1 \mathrm{ml}$ of QDs solution in serum-free medium (MEME containing penicillin-streptomycin and L-glutamine). QDs concentration solutions were as follows: 5, 25, 50, 75 and $100 \mu \mathrm{M}$ of $\mathrm{Cd}^{2+}$ ions. Subsequently, the solutions from over the cell monolayers containing populations of dead cells were collected to $5 \mathrm{ml}$ flow cytometry tubes. The cells were washed with $1 \mathrm{ml}$ PBS and incubated with $1 \mathrm{ml}$ of Tryple Express for 3-5 min to detach the cells from the plate's surface. The cell suspensions were transferred to the pre-labeled flow cytometry tubes and centrifuged (RCF $380 \times g, 3 \mathrm{~min}$ ).

\section{The type of cell death}

One of the stage of apoptosis is an asymmetry of the cell membrane resulting in an exposition of phosphatidylserine with preserving the membrane integrity. Annexin $\mathrm{V}$ is the protein, which specifically binds to phosphatidylserine in a presence of calcium ions. Annexin V conjugated to fluorescein isothiocyanate (FITC) was used to stain apoptotic cells. Propidium iodide (PI) is an organic dye that intercalates into the nucleic acid of cells with disrupted membrane (Pietkiewicz et al. 2015; Zhang and Liang 2014). Therefore, PI was used to stain necrotic cells. Flow cytometry was applied to simultaneous measurement of green and red fluorescence deriving from FITC and PI, respectively.

The type of cell death (an effect of cells incubation with nanoparticles) was determined with the Annexin V-FITC/ PI apoptosis/necrosis detection kit. A staining of cells was performed according to the manufacturer's instructions. Briefly, cells were washed twice with $2 \mathrm{ml}$ of PBS and then centrifuged. Then, $100 \mu \mathrm{l}$ of Annexin V binding solution, $5 \mu \mathrm{l}$ of FITC labeled Annexin V solution, and $5 \mu \mathrm{l}$ of propidium iodide solution were added to each flow cytometry tube. The cells were incubated with dyes solution for $15 \mathrm{~min}$ at a room temperature in a dark. After incubation additional volume of Annexin $\mathrm{V}$ binding solution (400 $\mu \mathrm{l})$ was added and cells were analyzed using a flow cytometer. The fluorescence intensity of cells stained with Annexin V-FITC and/or PI was measured using channels FL-1 and FL-3, respectively. During flow cytometry analysis, the data was recorded as a number of cells (red spots) on the plot (Fig. 1). Analyzed cells were divided into 4 populations (four areas in Fig. 1b) based on the mechanism of the dye staining: bottom left-double-negative, no external phosphatidylserine or DNA binding means these are viable cells; upper left-PI single-positive: necrotic, membranes disintegrated; bottom right-Annexin V-FITC single-positive, undergoing early apoptosis, nucleus is not yet permeable; upper right-double-positive, both external phosphatidylserine and membrane instability means late apoptosis or necrosis.

The flow cytometry software was used to quantify number of cells in each square and in this way this percentage of cell populations was calculated

The fluorescence intensity was measured using Cell Quest Pro software. At least 10,000 cells were analyzed in the case of each sample.

\section{Reactive oxygen species}

$2^{\prime}, 7^{\prime}$-Dichlorofluorescein diacetate (DCFH-DA) is a non-fluorescent compound, which is converted to its non-permeable derivative $2^{\prime}, 7^{\prime}$-dichlorofluorescein (DCFH) after cell internalization. In a presence of reactive oxygen species, this form is oxidized to $2^{\prime}, 7^{\prime}$-dichlorofluorescein (DCF), which exhibits green fluorescence (Sangeetha et al. 2015; Chen et al. 2016; Dong et al. 2018).

The 2', $7^{\prime}$-dichlorofluorescein diacetate stock solution $(10 \mathrm{mM})$ was prepared by dissolving $500 \mu \mathrm{g}$ of this dye in $100 \mu$ l of dimethyl sulfoxide (DMSO). The ROS level determination in K562 cells was carried out using the following procedure. The cells were transferred from a culture (a)

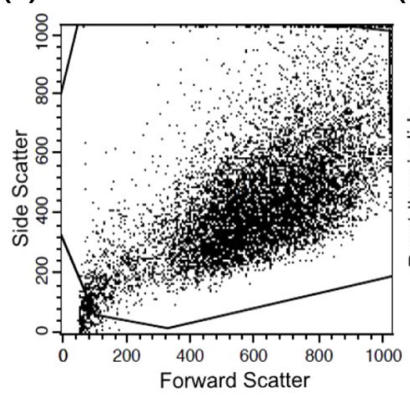

(b)

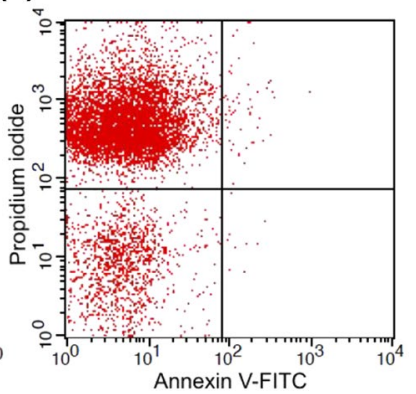

Fig. 1 Flow cytometry analysis of type of cell death. Data obtained for A549 cells incubated $24 \mathrm{~h}$ with CdSeS/ZnS-MPA QDs in concentration of $100 \mu \mathrm{M}$ of $\mathrm{Cd}^{2+}$. a plot with gated population of the cells, b dot plot of cells' populations: unstained and stained with Annexin V-FITC and/or PI 
flask, centrifuged, stained with trypan blue dye solution and counted. Then the cells were suspended in a serumfree medium containing $2^{\prime}, 7^{\prime}$-dichlorofluorescein diacetate $(20 \mu \mathrm{M})$ and seeded in 6-well plate in a volume of $500 \mu \mathrm{l}$ at a density of $5 \times 10^{5}$ cells per well. The same volume of QDs solutions was added to each well and mixed with cells, resulting in different QDs concentrations in wells: $0 \mu \mathrm{M}-$ control, 5, 25, 50, 75 and $100 \mu \mathrm{M}$. The cells were incubated at $37{ }^{\circ} \mathrm{C}$ in $5 \% \mathrm{CO}_{2}$ for $30 \mathrm{~min}$.

6-well plates were used for ROS tests, because in this way, higher number of cells were analyzed. During these tests changes of fluorescence intensity caused by generated ROS is measured. ROS is also generated in living cells; therefore, small fluorescence intensity is measured if the number of cells is low. Higher cells number used in tests are correlated to higher values of the measured fluorescence intensity and thus higher sensitivity of the analysis is achieved.

The ROS level in A549 and MRC-5 cells was evaluated using a procedure, which was adjusted to adherent cell lines. The cells were detached from a culture flask, centrifuged, stained with trypan blue and counted. The cells were seeded in 6-well plates at a density of $5 \times 10^{5}$ cells per well and incubated at $37{ }^{\circ} \mathrm{C}$ in $5 \% \mathrm{CO}_{2}$ overnight (time for cells adhesion to the surface). Then the medium was removed and replaced with QDs solutions $(0,5,25,50,75$ and $100 \mu \mathrm{M}$ of $\mathrm{Cd}^{2+}$ ). The cells were incubated for $30 \mathrm{~min}$. Then the medium was replaced with $20 \mu \mathrm{M}$ solution of $2^{\prime}, 7^{\prime}$-dichlorofluorescein diacetate in serum-free medium and the cells were incubated at $37{ }^{\circ} \mathrm{C}$ in $5 \% \mathrm{CO}_{2}$ for $30 \mathrm{~min}$.

Subsequently, the cells were collected to the flow cytometry tubes, washed with PBS and centrifuged (RCF $380 \times g$, $3 \mathrm{~min}$ ). This step was repeated four times to wash out the excess of the dye. The cells were suspended in $500 \mu \mathrm{l}$ of PBS and analyzed using flow cytometry.

\section{Results}

\section{Characterization of QDs}

High-quality quantum dots consisting of a core of a cadmium-based salt ( $\mathrm{CdS}$ or $\mathrm{CdSe})$ and a coat of $\mathrm{ZnS}$ obtained by organometallic synthesis are the most popular fluorescent nanocrystals. However, the QDs prepared using this method are coated with hydrophobic ligands (e.g., oleic acid or trioctylophosphine). Therefore, such QDs are not soluble in aqueous solutions. The modification of a surface of quantum dots with thiolated carboxylic acids aimed to the introduction of hydrophilic groups, which determined nanoparticles stability in aqueous solutions. Such nanocrystals gained negative charge in a culture medium, as a result of deprotonation of used modifiers that assures the stability as well as determines their surface properties and mechanism of interactions with cells. In addition, carboxyl groups can be potentially used for further conjugation with bioreceptors or therapeutic agents for the applications in theranostics.

Two types of quantum dots tested in a framework of the presented studies were characterized by significantly different diameters ( 3.7 vs. $6.0 \mathrm{~nm}$ ). Two homologous thiocarboxylic acids of different carbon chain length (C3-MPA vs. C6-MHA) were used as stabilizing ligands. These enabled the assessment of the impact of the nanoparticles' diameter on viability of the selected cell lines (evaluation QDs cytotoxicity). The structures of the examined quantum dots after modification with capping ligands are presented in detail in Table 1.

Due to the replacement of lipophilic ligands with thiolated carboxylic acids, the tested colloidal nanocrystals gained the water-solubility, which manifested as a discoloration of chloroform and the appearance of colored, fluorescent nanocrystals in an aqueous phase after the transfer process. A particularly important aspect for biological applications is a good colloidal stability, since the size of the structures substantially affects the way of interaction with cells and thus toxicity of QDs. Therefore, the requirement of maintaining a good dispersion of the obtained nanostructures should be taken into account during purification and treatment steps just after the ligand exchange. In contrast to the most commonly used methodologies, utilizing subsequent precipitation and resuspending, the applied approach of purification via dialysis does not require.

Due to the replacement of lipophilic ligands with thiolated carboxylic acids, the tested colloidal nanocrystals gained the water-solubility, which manifested as a

Table 1 Schemes of water-soluble QDs structures after surface modification with thiocarboxylic acids

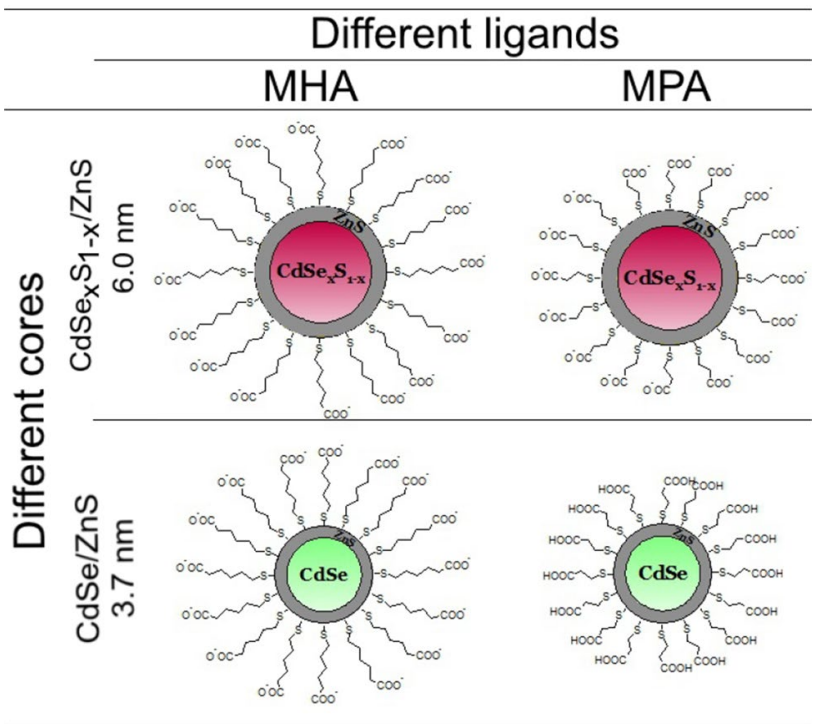


discoloration of chloroform and the appearance of colored, fluorescent nanocrystals in an aqueous phase after the transfer process. A particularly important aspect for biological applications is a good colloidal stability, since the size of the structures substantially affects the way of interaction with cells and thus toxicity of QDs. Therefore, the requirement of maintaining a good dispersion of the obtained nanostructures should be taken into account during purification and treatment steps just after the ligand exchange. In contrast to the most commonly used methodologies, utilizing subsequent precipitation and resuspending, the applied approach of purification via dialysis does not require precipitation of the nanocrystals. It assures a removal of low-molecular weight contaminants and at the same time adjusting $\mathrm{pH}$ of the solution (alkaline after phase transfer) to the desired value. This method prevents QDs from aggregation and enables effective purification and desalination without substantial loss of nanocrystals caused by aggregation. The concentration of free thiols in the dialysate after second dialysis (in equilibrium with free ligands in the QDs sample, total $C_{\mathrm{Cd}^{2+}} \approx 1.0 \mathrm{mM}$ ) was undetectable by spectrophotometric Ellman's method $\left(C_{\text {thiol }}<10 \mu \mathrm{M}\right)$. Concentration of free cadmium ions in the QDs sample after ligand exchange is negligibly low (at the level of $0.2 \%$ of total cadmium concentration), based on the $\mathrm{Cd}^{2+}$ determination in supernatant obtained as a result of quantitative centrifugation of QDs. This proves that the dominant form of this element is the Cd-chalcogenide salt in the nanocrystal core.

Exemplary TEM images of the mixed core nanocrystals $\left(\mathrm{CdSe}_{x} \mathrm{~S}_{1-x} / \mathrm{ZnS}\right)$ and uniform core ones $(\mathrm{CdSe} / \mathrm{ZnS})$ are depicted in Fig. 2. As resulted from analysis of TEM micrographs, the applied procedures of ligand exchange prevent QDs from aggregation while not alternating core diameters of the tested nanocrystals.

Conducted DLS studies allowed for comparative studies of hydrodynamic diameters depending on the QD diameter as well as a type of a surface ligand.

As presented in Fig. 3, low-molecular weight thiol derivatives increased a hydrodynamic diameter of the

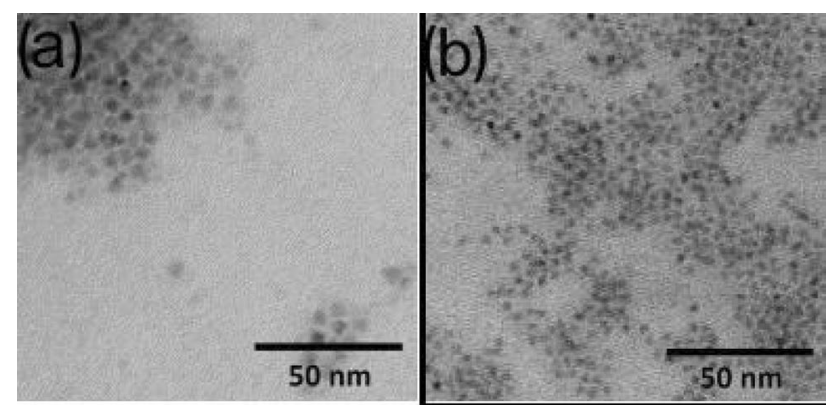

Fig. 2 TEM micrographs of $\mathrm{CdSe}_{x} \mathrm{~S}_{1-x} / \mathrm{ZnS}$ QDs (a) and CdSe/ZnS QDs (b) modified with MHA

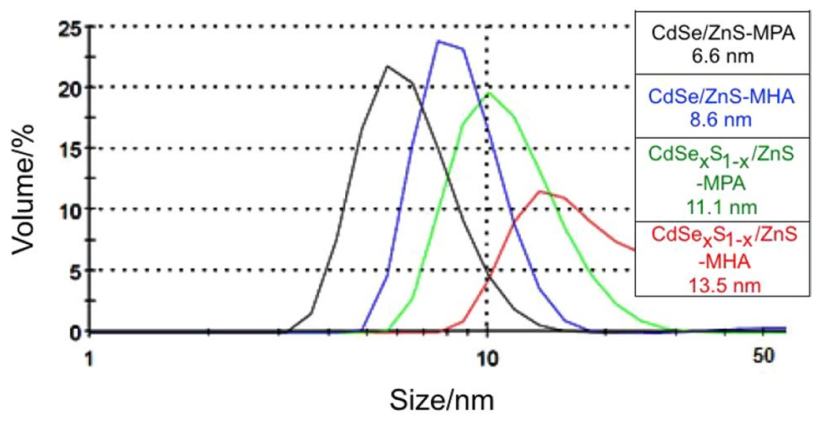

Fig. 3 Hydrodynamic diameters of CdSe/ZnS-MPA (dots), CdSe/ ZnS-MHA (filled circle), $\mathrm{CdSe}_{x} \mathrm{~S}_{1-x} / \mathrm{ZnS}-\mathrm{MPA}$ (dots), CdSe $\mathrm{S}_{1-x} /$ ZnSMHA (dots), measured by dynamic light scattering

nanostructures to 6.6 and $11.1 \mathrm{~nm}$ for $\mathrm{CdSe} / \mathrm{ZnS}$ and $\mathrm{CdSe}_{x} \mathrm{~S}_{1-x} / \mathrm{ZnS}$ QDs, respectively. This feature is particularly important as it can have the influence on the interaction of QDs with cells, their transmembrane transport and a mechanism of toxicity. DLS analysis confirmed a good dispersion of nanoparticles and allowed to observe differences in hydrodynamic diameters depending on the aliphatic chain length of the modifiers. In both cases, a hydrodynamic diameter was increased (about $2 \mathrm{~nm}$ ) for the structures stabilized with MHA in comparison with the nanocrystals coated with MPA.

The mixed core $\mathrm{CdSe}_{x} \mathrm{~S}_{1-x} / \mathrm{ZnS}$ QDs of a diameter of $6.0 \mathrm{~nm}$ emitted fluorescence at $625 \mathrm{~nm}$, in turn $3.7 \mathrm{~nm}$ $\mathrm{CdSe} / \mathrm{ZnS}$ at $525 \mathrm{~nm}$ (Fig. 4). The differences in the absorption and emission bands resulted from different core components and various sizes of tested QDs. There was no significant effect of the type of ligand on the absorption and fluorescence spectra (data not shown). The analysis of the absorption spectrum confirmed the high quality of the obtained QDs. The analysis of the fluorescence intensity of quantum dots leads to the conclusion that for the same cores, MHA-stabilized nanocrystals are characterized by higher quantum yields than MPA-capped ones (data not shown). It is probably caused by the higher surface density of MHA ligands and better surface passivation assured by MHA. Nevertheless, regardless of the nanocrystal and the ligand type, all QDs samples exhibit sufficient fluorescence for biological studies in the range of concentrations which were used in our tests.

The long-term stability of physicochemical parameters of nanocrystals after the surface modification was determined by the series of optical measurements (absorption and fluorescence spectra). In the case of QDs stabilized with thiocarboxylic acids, excellent stability of morphology and fluorescence intensity during at least 3 months storage was observed. 

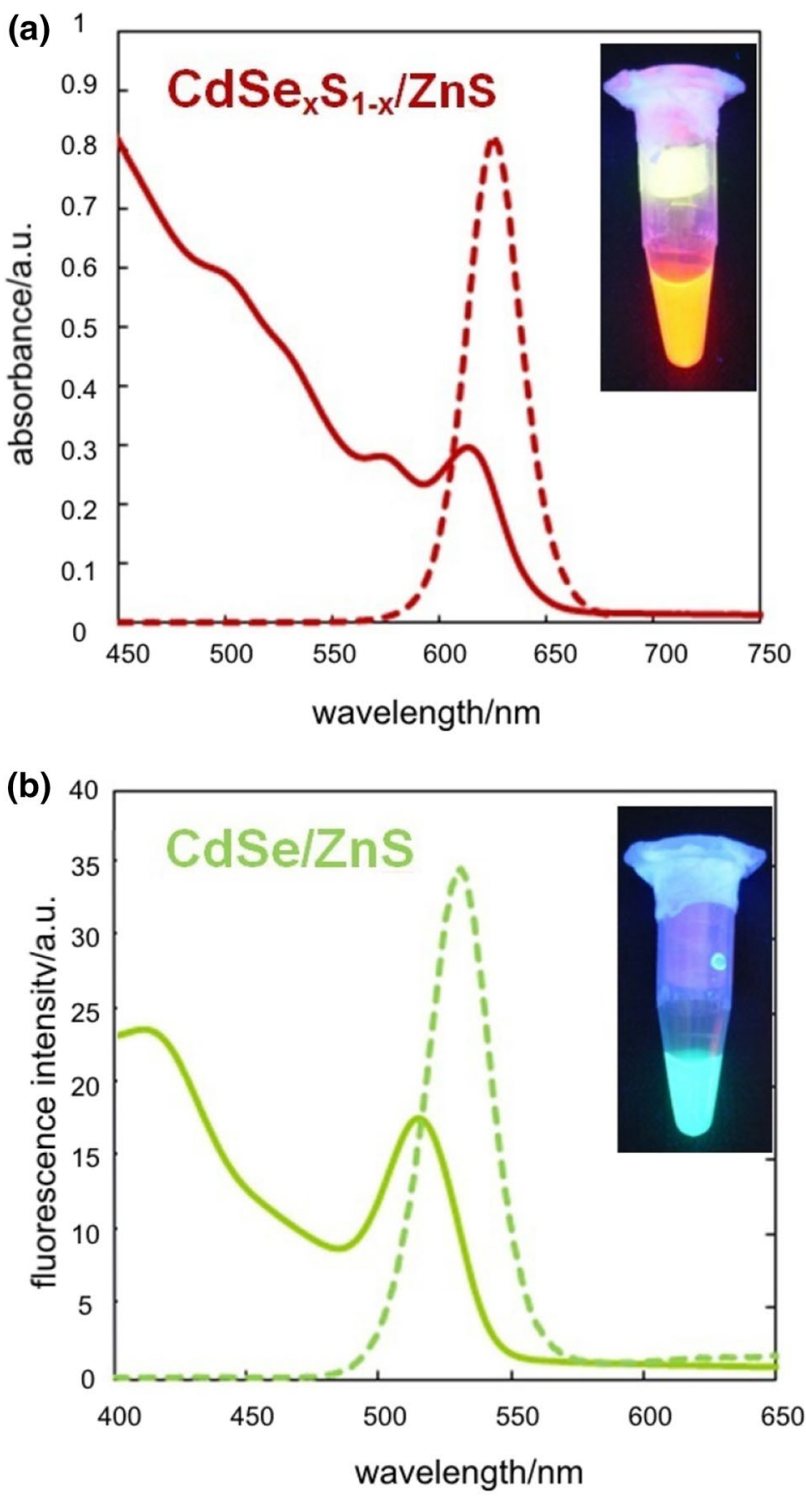

Fig. 4 Absorption (solid line) and emission (dotted line) spectra of $\mathrm{CdSe}_{x} \mathrm{~S}_{1-x} / \mathrm{ZnS}$ QDs (red) and CdSe/ZnS (green)

\section{Cytotoxicity of QDs}

The toxicity of four types of QDs: $\mathrm{CdSe}_{x} \mathrm{~S}_{1-x} / \mathrm{ZnS}-\mathrm{MPA}$, $\mathrm{CdSe}_{x} \mathrm{~S}_{1-x} / \mathrm{ZnS}-\mathrm{MHA}, \mathrm{CdSe} / \mathrm{ZnS}-\mathrm{MPA}, \mathrm{CdSe} / \mathrm{ZnS}-\mathrm{MHA}$ was determined with flow cytometry using annexin V-FITC and PI staining. The study was conducted on the selected cell lines (K562 and A549).

Figure 5 shows the results of the cytotoxicity tests of $\mathrm{CdSe} / \mathrm{ZnS}$ QDs on both cell lines. As presented in the graph, the viability of cells decreased while increasing concentrations of $\mathrm{CdSe} / \mathrm{ZnS}-\mathrm{MPA}$ and $\mathrm{CdSe} / \mathrm{ZnS}-\mathrm{MHA}$ QDs. It was observed for K562 cells, as well as for A549 cell line. $\mathrm{CdSe} / \mathrm{ZnS}-\mathrm{MHA}$ were less toxic than $\mathrm{CdSe} / \mathrm{ZnS}$ modified with 3-mercaptohexanoic acid. For the highest examined
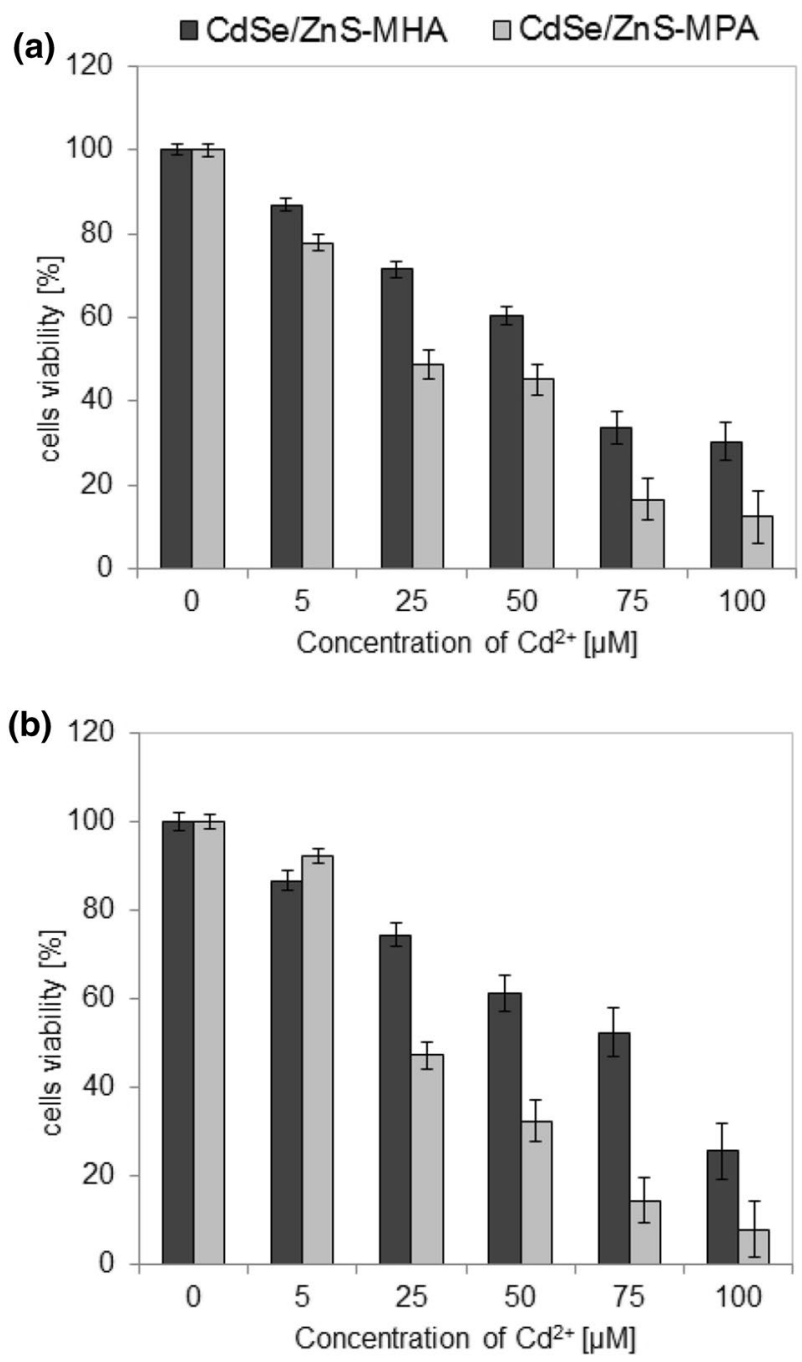

Fig. 5 Comparison of CdSe/ZnS-MHA and CdSe/ZnS-MPA QDs toxicity on: a K562, b A549 cells after $24 \mathrm{~h}$ of incubation. The number of living cells is presented as the percent referred to the control

concentration of QDs solutions $\left(100 \mu \mathrm{M}\right.$ of $\left.\mathrm{Cd}^{2+}\right)$, the viability of K562 cells exposed to CdSe/ZnS-MHA solution decreased to $30 \%$, whereas exposure to the same concentration of cadmium ions contained in $\mathrm{CdSe} / \mathrm{ZnS}-\mathrm{MPA}$ decreased the viability of K562 cells to $12 \%$. In the case of concentration of $75 \mu \mathrm{M}$ the difference between the toxicity of QDs modified with MPA and MHA ligands was even higher, resulting in 52 and $15 \%$ viability of A549 cells exposed to CdSe/ZnS-MHA and CdSe/ZnS-MPA, respectively.

The results of flow cytometry analysis of K562 and A549 cells exposed to $\mathrm{CdSe}_{x} \mathrm{~S}_{1-x} / \mathrm{ZnS}$ QDs with surface modified with 6-mercaptohexanoic acid or 3-mercaptohexanoic acid are presented in Fig. 6. The toxicity of the QDs depended on the nanoparticles concentration and the type of the ligand as well. The higher toxicity was observed for QDs with the surface modified using MPA in comparison with QDs covered

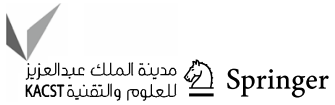



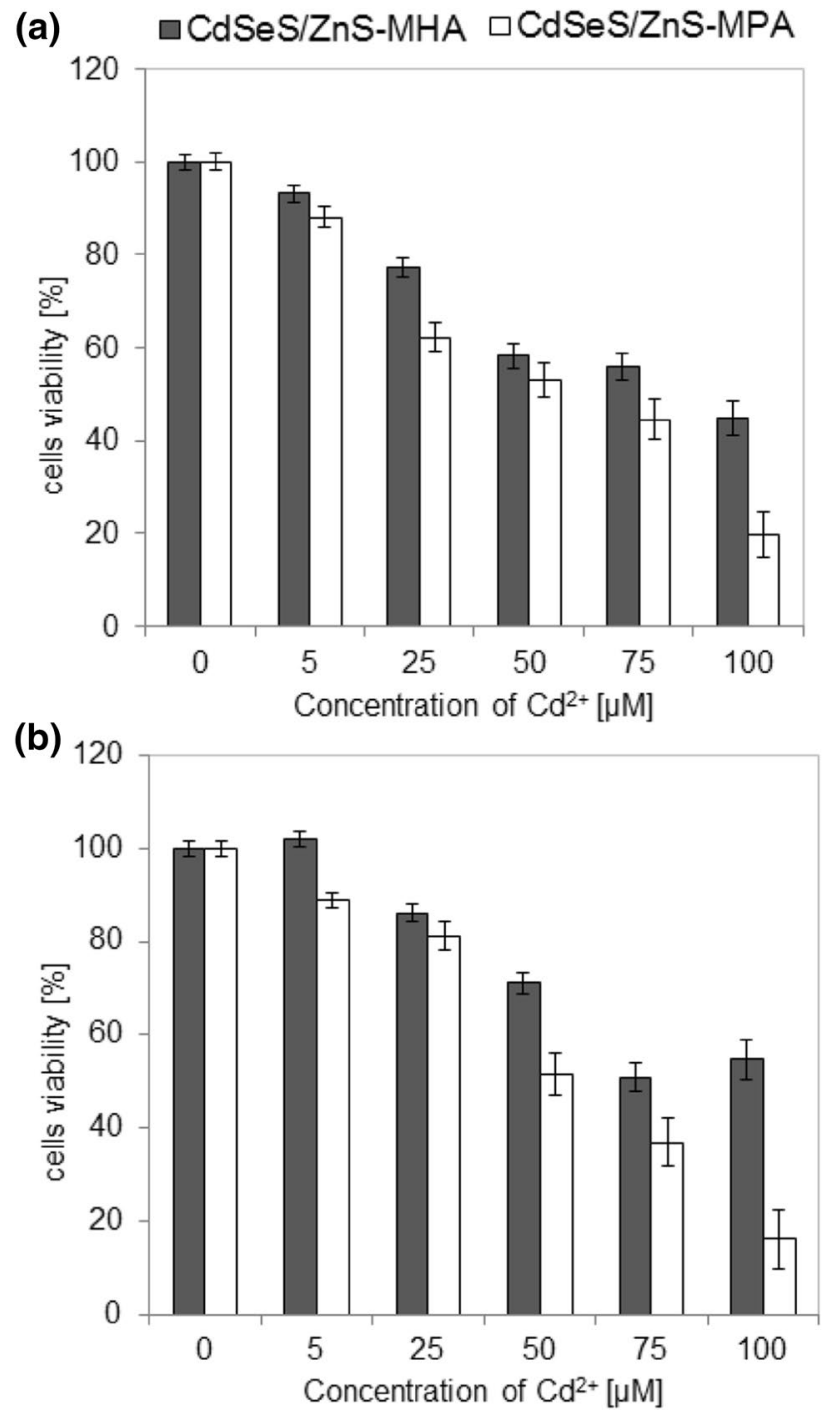

Fig. 6 Comparison of $\mathrm{CdSe}_{x} \mathrm{~S}_{1-x}$ /ZnS-MHA (CdSeS/ZnS-MHA) and $\mathrm{CdSe}_{x} \mathrm{~S}_{1-x} / \mathrm{ZnS}-\mathrm{MPA}$ (CdSeS/ZnS-MPA) QDs toxicity on: a $\mathrm{K} 562$, b A549 cells after $24 \mathrm{~h}$ of incubation. The number of living cells is presented as the percent referred to the control

with a longer ligand (MHA). The viability of K562 cells exposed to the concentration of $25 \mu \mathrm{M}$ decreased to $62 \%$ after exposure to $\mathrm{CdSe}_{x} \mathrm{~S}_{1-x} / \mathrm{ZnS}-\mathrm{MPA}$, while a number of living cells amounted to $77 \%$ for $\mathrm{CdSe}_{x} \mathrm{~S}_{1-x} / \mathrm{ZnS}-\mathrm{MHA}$. Similarly, the $\mathrm{CdSe}_{x} \mathrm{~S}_{1-x} / \mathrm{ZnS}-\mathrm{MPA}$ QDs turned out to be more toxic than $\mathrm{CdSe}_{x} \mathrm{~S}_{1-x} / \mathrm{ZnS}-\mathrm{MHA}$ QDs to A549 cells as well. A549 treated with $50 \mu \mathrm{M}$ of QDs were viable in $71 \%$ and only in $52 \%$ for $\mathrm{CdSe}_{x} \mathrm{~S}_{1-x} / \mathrm{ZnS}-\mathrm{MHA}$ and $\mathrm{CdSe}_{x} \mathrm{~S}_{1-x}$ l ZnS-MPA, respectively. For higher QDs concentration larger differences in the toxicity depending on the surface modification were observed. The highest examined QDs concentration (of $100 \mu \mathrm{M}$ of cadmium cations) resulted in the decrease of the viability to $20 \%$ for K562 cells in the case of $\mathrm{CdSe}_{x} \mathrm{~S}_{1-x} / \mathrm{ZnS}-\mathrm{MPA}$, while it was more than twice higher (45\%) in the case of $\mathrm{CdSe}_{x} \mathrm{~S}_{1-x} / \mathrm{ZnS}-\mathrm{MHA}$. The viability of A549 cells exposed to the same concentration of QDs amounted to $16 \%$ for $\mathrm{CdSe}_{x} \mathrm{~S}_{1-x} / \mathrm{ZnS}-\mathrm{MPA}$ and $55 \%$ for $\mathrm{CdSe}_{x} \mathrm{~S}_{1-x} / \mathrm{ZnS}-\mathrm{MHA}$.

The viability of cells was higher after exposure to $\mathrm{CdSe}_{x} \mathrm{~S}_{1-x} / \mathrm{ZnS}$ than to $\mathrm{CdSe} / \mathrm{ZnS}$ QDs with the same surface modification. The application of QDs in medicine or biology in the majority of cases requires the utilization of QDs of limited toxicity; therefore, $\mathrm{CdSe}_{x} \mathrm{~S}_{1-x} / \mathrm{ZnS}$ QDs exhibiting lower cytotoxicity were selected for cytotoxicity tests with normal MRC- 5 cell line. The results of toxicity studies in the case of $\mathrm{CdSe}_{x} \mathrm{~S}_{1-x} / \mathrm{ZnS}-\mathrm{MHA}$ and $\mathrm{CdSe}_{x} \mathrm{~S}_{1-x}$ ' ZnS-MPA QDs are presented in Fig. 7. Generally, for this cell line differences in the toxicity of QDs depending on their surface ligand for high concentrations of QDs solutions were not significant. However, for the solutions of 50 and $25 \mu \mathrm{M}$ the toxicity differed notably. For instance, the viability of MRC-5 cells was reduced to 78 and $52 \%$ after exposure to $\mathrm{CdSe}_{x} \mathrm{~S}_{1-x} / \mathrm{ZnS}-\mathrm{MHA}$ and $\mathrm{CdSe}_{x} \mathrm{~S}_{1-x} / \mathrm{ZnS}-\mathrm{MPA}$ QDs, respectively.

The $\mathrm{IC}_{50}$ values for all examined types of QDs are presented in Table 2 . The results of the toxicity for three cell

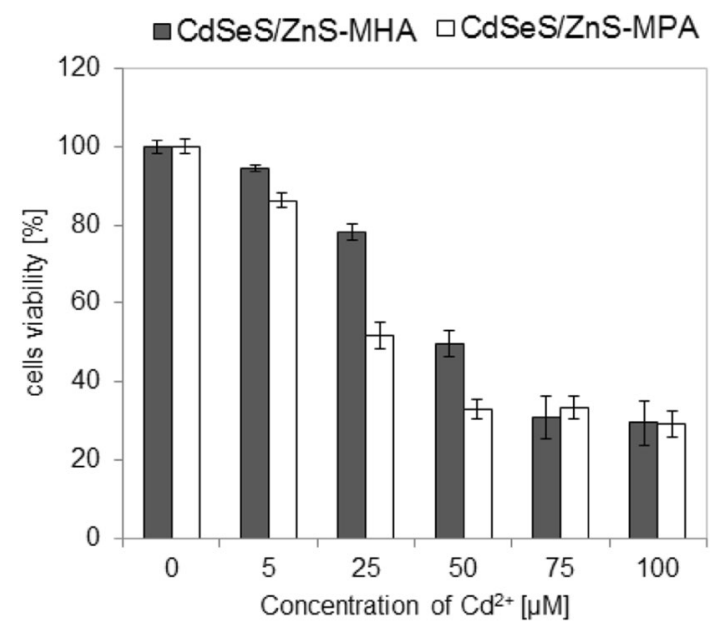

Fig. 7 Comparison of $\mathrm{CdSe}_{x} \mathrm{~S}_{1-x} / \mathrm{ZnS}-\mathrm{MHA}$ (CdSeS/ZnS-MHA) and $\mathrm{CdSe}_{x} \mathrm{~S}_{1-x} / \mathrm{ZnS}-\mathrm{MPA}$ (CdSeS/ZnS-MPA) QDs toxicity on MRC- 5 cells after $24 \mathrm{~h}$ of incubation. The number of living cells is presented as the percent referred to the control

Table $2 \mathrm{The} \mathrm{IC}_{50}$ values $\left[\mu \mathrm{M}\right.$ of $\left.\mathrm{Cd}^{2+}\right]$ for $\mathrm{K} 562$, A549 and MRC-5 after $24 \mathrm{~h}$ of incubation with different QDs solutions: $\mathrm{CdSe}_{x} \mathrm{~S}_{1-x}$ / $\mathrm{ZnS}$ with surface modified with 3-mercaptopropionic acid (MPA) or 6-mercaptohexanoic (MHA) and CdSe/ZnS

\begin{tabular}{llll}
\hline & K562 & A549 & MRC-5 \\
\hline $\mathrm{CdSe}_{x} \mathrm{~S}_{1-x} / \mathrm{ZnS}-\mathrm{MHA}$ & $84 \pm 3$ & $91 \pm 3$ & $54 \pm 2$ \\
$\mathrm{CdSe} / \mathrm{ZnS}-\mathrm{MHA}$ & $58 \pm 2$ & $67 \pm 3$ & \\
$\mathrm{CdSe}_{x} \mathrm{~S}_{1-x} / \mathrm{ZnS}-\mathrm{MHA}$ & $53 \pm 2$ & $56 \pm 2$ & $30 \pm 2$ \\
$\mathrm{CdSe} / \mathrm{ZnS}-\mathrm{MHA}$ & $32 \pm 1$ & $23 \pm 2$ & \\
\hline
\end{tabular}


lines were similar. The higher was the concentration of QDs solutions incubated with cell cultures, the higher toxicity was observed. QDs containing cores with larger diameter $\left(\mathrm{CdSe}_{x} \mathrm{~S}_{1-x} / \mathrm{ZnS}\right)$ exhibited lower cytotoxicity than CdSe/ $\mathrm{ZnS}$ (the same ligand on the surface). However, the surface modification had a stronger influence on the observed toxicity than the core composition of examined QDs. QDs with the surface modified with the longer ligand revealed to be less toxic than the nanoparticles modified with 3-mercaptopropionic acid. For instance, the $\mathrm{CdSe}_{x} \mathrm{~S}_{1-x} / \mathrm{ZnS}-\mathrm{MHA}$ QDs in the concentration of $5 \mu \mathrm{M}$ for all three cell lines were non-toxic, and the viability cells amounted to above $90 \%$ of the control.

\section{The type of cell death}

The type of cell death after $24 \mathrm{~h}$ exposure to different concentrations of QDs was determined. The results obtained for QDs exhibiting the lowest cytotoxicity $\left(\mathrm{CdSe}_{x} \mathrm{~S}_{1-x}{ }^{\prime}\right.$ ZnS-MHA) are presented in this manuscript. It should be pointed out that the results obtained for other types of the tested QDs were analogous. In Fig. 8, the comparison of the amount of necrotic and apoptotic cells expressed as the percentage of dead cells is shown for K562, A549 and MRC-5 cell lines. For all tested cell lines, the vast majority of dead cells underwent necrosis, ranging from over $80 \%$ for the lowest tested concentration to 99\% for QDs in the concentration of $50 \mu \mathrm{M}$ in a case of K562 cells. For MRC-5 cell line the percentage of necrotic cells was above $94 \%$ after exposure to QDs. In comparison with the whole cell population, the higher concentration of QDs was introduced to cell cultures, the more cells underwent necrosis.

\section{Reactive oxygen species}

The results of the evaluation of the reactive oxygen species generation after 30 min of incubation of K562, A549 and MRC-5 cells with $\mathrm{CdSe} \mathrm{S}_{1-x} / \mathrm{ZnS}-\mathrm{MPA}$ and $\mathrm{CdSe} \mathrm{S}_{1-x} /$ $\mathrm{ZnS}-\mathrm{MHA}$ are presented in Fig. 9. For all three cell lines, ROS level increased when increasing the amount of QDs, which were in contact with the cells. For the lowest tested concentration $\left(5 \mu \mathrm{M}\right.$ of $\left.\mathrm{Cd}^{2+}\right)$ the ROS generation was comparable to the control. However, in the case of higher concentrations, the ROS level raised significantly in comparison with the control sample. The ROS level in the case of K562 cells sample amounted to 275 and $249 \%$ for $100 \mu \mathrm{M}$ of QDs CdSe $\mathrm{S}_{1-x} / \mathrm{ZnS}-\mathrm{MPA}$ and $\mathrm{CdSe}_{x} \mathrm{~S}_{1-x} / \mathrm{ZnS}-\mathrm{MHA}$, respectively. Similarly, in the case of A549 cell, the level of ROS increased after the incubation with QDs solutions. For the highest tested concentration of QDs, the ROS level after $30 \mathrm{~min}$ of the exposure to $\mathrm{CdSe}_{x} \mathrm{~S}_{1-x} / \mathrm{ZnS}-\mathrm{MPA}$ raised to $257 \%$, while for $\mathrm{CdSe}_{x} \mathrm{~S}_{1-x} / \mathrm{ZnS}-\mathrm{MHA}$, it amounted to $309 \%$. For K562 and A549 cell lines, the difference (a) $\square$ early apoptosis $\square$ late apoptosis/necrosis $\square$ necrosis
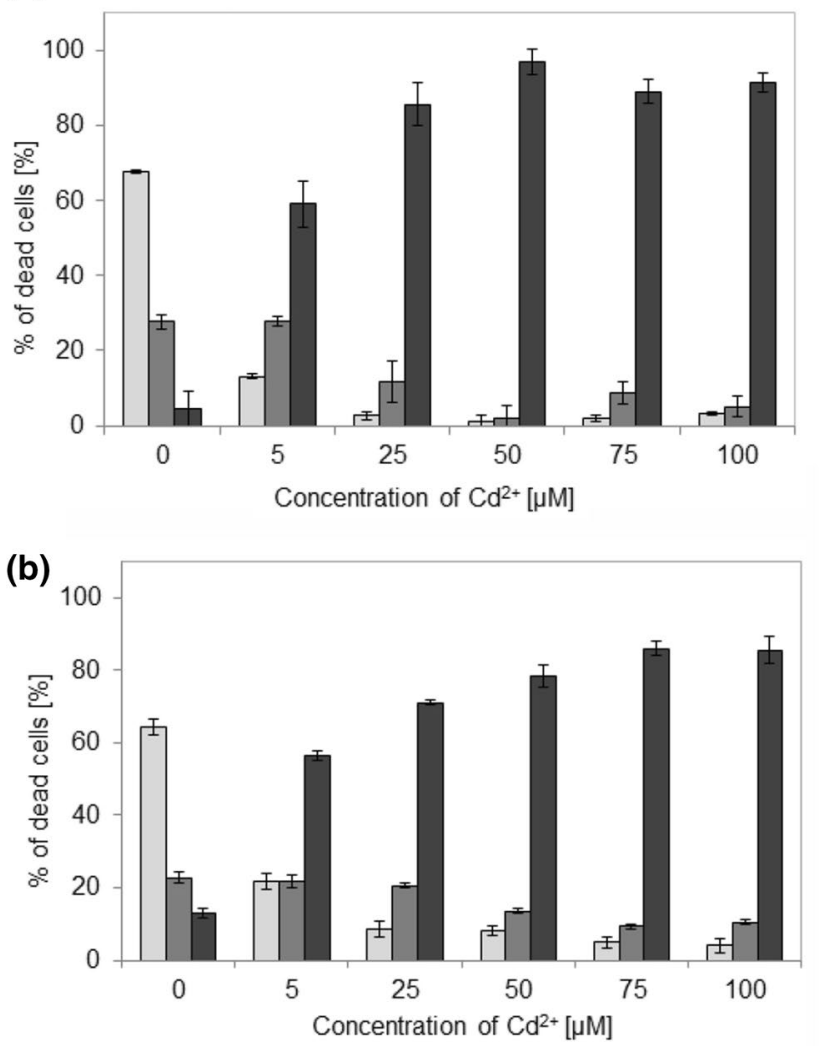

(c)

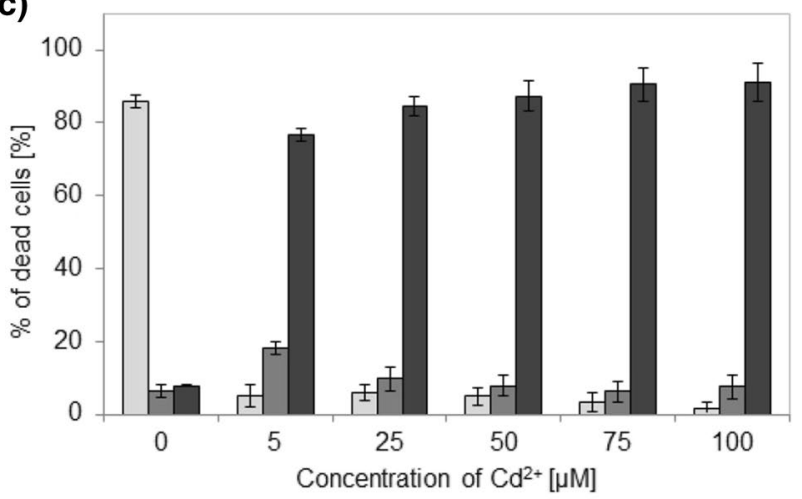

Fig. 8 The number of cells in early apoptosis (light gray), late apoptosis/necrosis (gray) and necrosis (dark gray); values are expressed as a percentage of dead cells after 24 h exposure of: a K562, b A549, c MRC-5 cells to CdSe $\mathrm{S}_{1-x} / \mathrm{ZnS}-\mathrm{MHA}$ QDs

between the amount of ROS generated after incubation with $\mathrm{CdSe}_{x} \mathrm{~S}_{1-x} / \mathrm{ZnS}-\mathrm{MPA}$ in comparison with $\mathrm{CdSe}_{x} \mathrm{~S}_{1-x} /$ ZnS-MHA was not observed, in contrast to the results obtained for MCR-5. For all tested concentrations of QDs solutions, ROS level was increased in MRC-5 cells after the incubation with QDs $\mathrm{CdSe}_{x} \mathrm{~S}_{1-x} / \mathrm{ZnS}-\mathrm{MPA}$, which exhibited higher toxicity in comparison with $\mathrm{CdSe}_{x} \mathrm{~S}_{1-x} / \mathrm{ZnS}-\mathrm{MHA}$. For $\mathrm{CdSe}_{x} \mathrm{~S}_{1-x} / \mathrm{ZnS}-\mathrm{MPA}$ and $\mathrm{CdSe}_{x} \mathrm{~S}_{1-x} / \mathrm{ZnS}-\mathrm{MHA} \mathrm{QDs}$ in a concentration of $100 \mu \mathrm{M}$ ROS level amounted to 361 and $241 \%$ of the control, respectively. On the basis of these

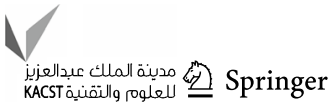


Fig. 9 The reactive oxygen species levels after $30 \mathrm{~min}$ exposure of a K562, b A549, c MRC-5 cells to CdSe $\mathrm{S}_{1-x} / \mathrm{ZnS}-\mathrm{MHA}$ (CdSeS/ $\mathrm{ZnS}-\mathrm{MHA})$ and $\mathrm{CdSe}_{x} \mathrm{~S}_{1-x} / \mathrm{ZnS}-\mathrm{MPA}(\mathrm{CdSeS} / \mathrm{ZnS}-\mathrm{MPA})$ QDs

results, it can be concluded that cytotoxicity mechanism of the examined QDs is tightly related to the reactive oxygen species generation.

\section{Conclusions and discussion}

In the case of studies, which objective is to determine and compare the toxicity of two or more types of the nanoparticles, the relevant aspect is to define the nanoparticles concentration in an appropriate way. In our opinion, it is very important to describe the way how the concentration of the nanomaterials was determined, so that the results described by different research groups could be compared. In some studies, the concentration of the nanoparticles is expressed as a number of particles per volume (Fratoddi et al. 2015) or a mass of nanoparticles per volume (Silva et al. 2016; Yan et al. 2016). In this case, the solutions containing the same number of the nanoparticles may have various cadmium content. Such approach does not allow for comparison of different QDs properties when a diameter and a composition of their cores differ. Since cadmium is considered to be the main cause of QDs toxicity, in our opinion the better approach is to express the concentration of these nanomaterials as a cadmium concentration (Peuschel et al. 2016). Therefore, we were able to compare the biological activity of QDs with different surface modifications and of different cores as well. In the framework of this study we presented that flow cytometry is a good technique for the analysis of not only suspension cells, but also adherent ones after enzymatic detachment from the surface of a culture dish.

The cytotoxicity of the nanomaterials and the type of cell death, which they cause may depend on the exposure time, cell type, as well as concentration and composition (material of both core and shell, and the surface modification) of the nanomaterials (Hardman 2006). Our results revealed that all four types of the tested QDs exhibited toxicity. The higher concentrations of QDs were incubated with cell cultures, the lower viability was observed. However, the lowest tested QDs concentration $\left(5 \mu \mathrm{M}\right.$ of $\left.\mathrm{Cd}^{2+}\right)$ did not cause the death of a significant number of cells and then the cell viability exceeded $90 \%$ of the control. After careful examination of the toxicity of QDs composed of two types of cores $\left(\mathrm{CdSe} / \mathrm{ZnS}\right.$ and $\left.\mathrm{CdSe}_{x} \mathrm{~S}_{1-x} / \mathrm{ZnS}\right)$ with the surface modified using two different ligands (MHA and MPA) to K562 and A549 cells, it can be concluded that the modification of QDs surface affects the QDs cytotoxicity. Both types of QDs (CdSe/ZnS and $\left.\mathrm{CdSe}_{x} \mathrm{~S}_{1-x} / \mathrm{ZnS}\right)$ exhibited lower toxicity while modified with a longer ligand
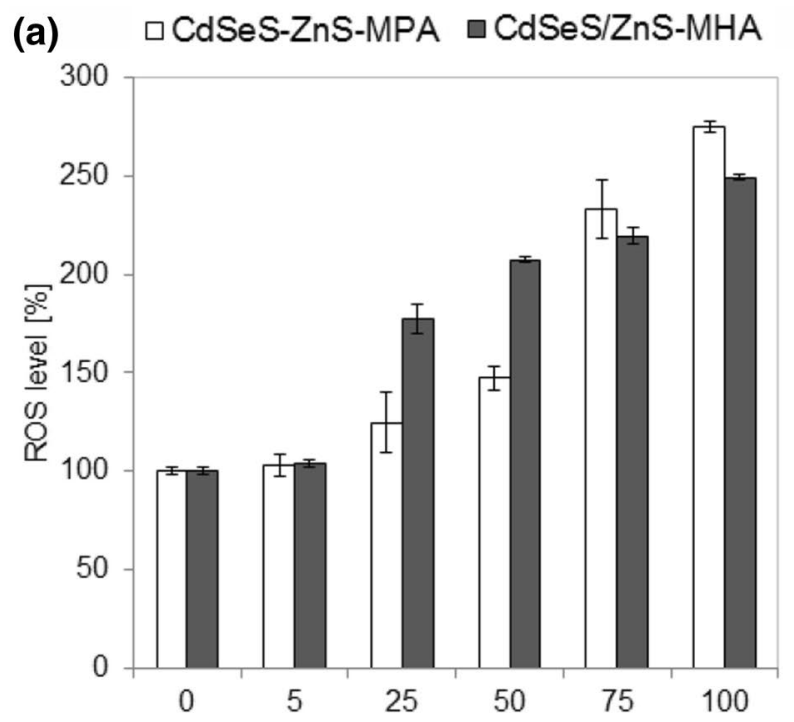

(b)

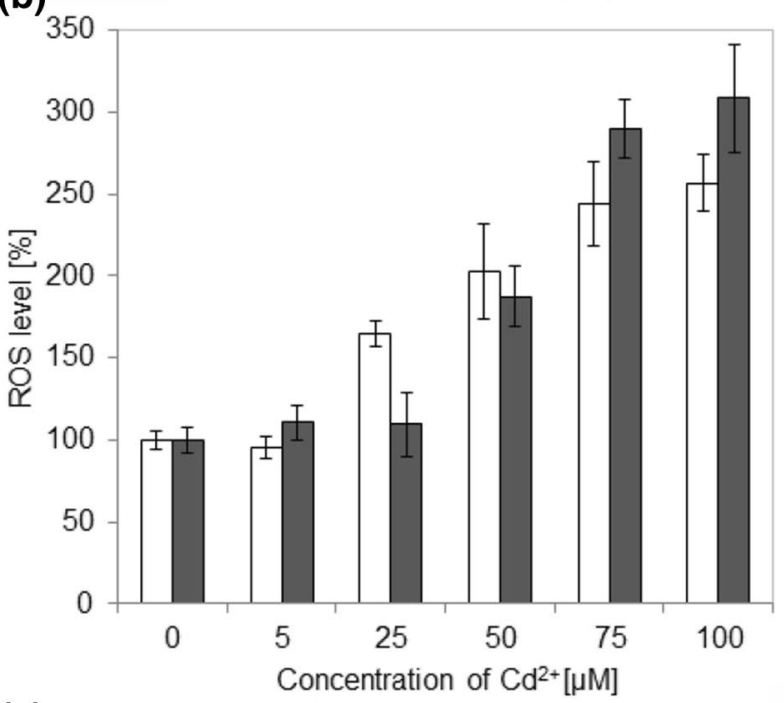

(c)

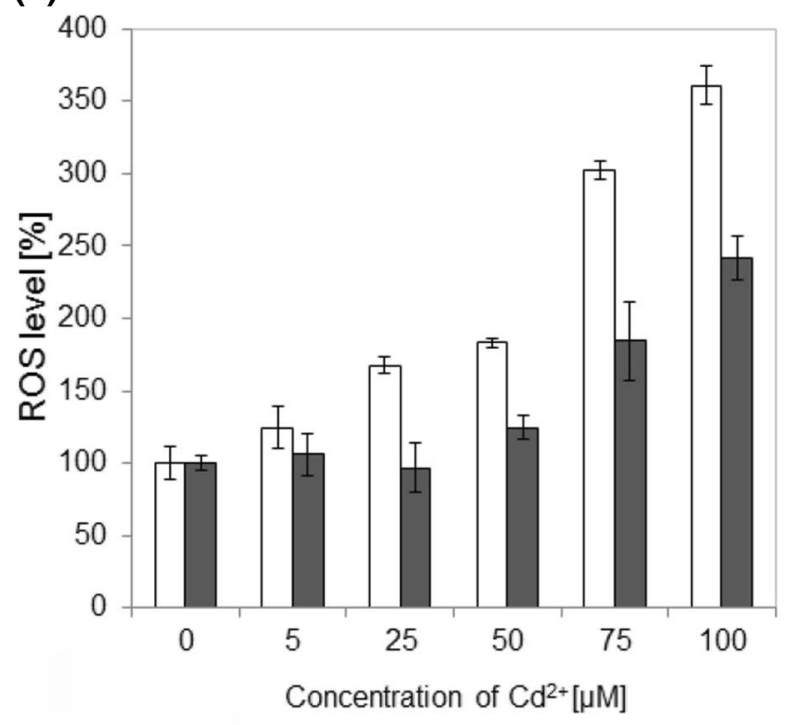


(MHA). Similarly, the results of the studies on normal cell line confirmed that modification of QDs surface with longer ligand (MHA) decreases the QDs toxicity. There are some studies indicating that the toxicity of cadmiumbased QDs is dependent on QDs size (Lovrić et al. 2005; Shiohara et al. 2004; Zhang et al. 2007). Smaller QDs may be able to penetrate cells more easily than larger ones. According to our studies, the toxicity of QDs is much stronger related to the length of the modifier's chain then to the hydrodynamic size of QDs, e.g., smaller $(8.6 \mathrm{~nm})$ CdSe/ZnS-MHA QDs exhibited lower toxicity than more spacious $(11.1 \mathrm{~nm}) \mathrm{CdSe}_{x} \mathrm{~S}_{1-x} / \mathrm{ZnS}-\mathrm{MPA}$ QDs. This may be due to the fact that longer ligand provides a better protection of the core and reduces the release of toxic $\mathrm{Cd}^{2+}$ ions from the core to the cell culture environment. The obtained results are in good correlation with the previous work of our group (Grabowska-Jadach et al. 2016b). Those studies revealed that $\mathrm{CdSe}_{x} \mathrm{~S}_{1-x} / \mathrm{ZnS}$ QDs modified with MHA exhibited lower toxicity than $\mathrm{CdSe}_{x} \mathrm{~S}_{1-x}$ l ZnS-MPA QDs. However, the differences in the viability levels may be a result of different conditions of cell culture (a microsystem with a continuous flow vs. static macroscale culture).

The annexin V-FITC/PI assay showed that the cells after incubation with QDs, regardless of their type, died through necrosis. For K562 and A549 cell lines, it can be concluded that the higher concentration of QDs, the more cells underwent necrosis. The MRC-5 cell line exhibited a higher percentage of necrotic cells for all tested QDs concentrations.

In addition, the reactive oxygen species production after 30 min of incubation with $\mathrm{CdSe}_{x} \mathrm{~S}_{1-x} / \mathrm{ZnS}-\mathrm{MPA}$ and $\mathrm{CdSe}_{x} \mathrm{~S}_{1-x} / \mathrm{ZnS}-\mathrm{MHA}$ QDs solutions was evaluated. For three tested cell lines, the level of ROS was higher after the increase the concentration of QDs. According to the obtained results, it may be concluded that cytotoxicity of QDs is related to ROS generation.

To sum up, we compared the biological activity of selected QDs with the same cores and different ligands: CdSe/ZnS-MHA, CdSe/ZnS-MPA, CdSe $\mathrm{S}_{1-x} / \mathrm{ZnS}-\mathrm{MHA}$ and $\mathrm{CdSe}_{x} \mathrm{~S}_{1-x} / \mathrm{ZnS}-\mathrm{MPA}$. Our study confirmed that QDs surface modification affects QDs toxicity; therefore, an appropriate modification can allow reducing the toxicity of the nanoparticles. For instance, to use some nanomaterials safely, we can choose longer surface ligands to modify the QDs surface and use them in low concentrations. However, more advanced cytotoxicity studies are required to gain knowledge about nanomaterials properties in a complex biological environment, only then we can safely use them, e.g., for cells staining in living organisms.

Acknowledgements The research was performed within the project of SONATA funded by the National Science Centre UMO-2013/09/D/ ST5/03832.
Open Access This article is distributed under the terms of the Creative Commons Attribution 4.0 International License (http://creativeco mmons.org/licenses/by/4.0/), which permits unrestricted use, distribution, and reproduction in any medium, provided you give appropriate credit to the original author(s) and the source, provide a link to the Creative Commons license, and indicate if changes were made.

\section{References}

Adan A, Alizada G, Kiraz Y, Baran Y, Nalbant A (2016) Flow cytometry: basic principles and applications. Crit Rev Biotechnol 14:1-14

Avelar-Freitas BA, Almeida VG, Pinto MC, Mourão FA, Massensini AR, Martins-Filho OA, Rocha-Vieira E, Brito-Melo GE (2014) Trypan blue exclusion assay by flow cytometry. Braz J Med Biol Res 47:307-315

Bagher AM (2016) Quantum dots applications. Sens Transducers 198:37-43

Bruneau A, Fortier M, Gagne F, Gagnon C, Turcotte P, Tayabali A, Davis TA, Auffret M, Fournier M (2015) In vitro immunotoxicology of quantum dots and comparison with dissolved cadmium and tellurium. Environ Toxicol 30:9-25

Casas JS, García-Tasende MS, Sánchez A, Sánchez-González A, Sordo J, Touceda A, Vázquez-González M (2014) Synthesis, characterization and in vitro toxicity assessment of DMPScapped CdTe quantum dots. Polyhedron 70:77-84

Chandan HR, Schiffman JD, Balakrishna RG (2018) Quantum dots as fluorescent probes: Synthesis, surface chemistry, energy transfer mechanisms, and applications. Sens Actuators B 258:1191-1214

Chen N, He Y, Su Y, Li X, Huang Q, Wang H, Zhang X, Tai R, Fan C (2012) The cytotoxicity of cadmium-based quantum dots. Biomaterials 33:1238-1244

Chen G, Li SY, Malik HT, Ma YG, Xu H, Sun LK (2016) Organic two-photon nanoparticles modulate reactive oxygen species, intracellular calcium concentration, and mitochondrial membrane potential during apoptosis of human gastric carcinoma SGC-7901 cells. Biotechnol Lett 38(8):1269-1276

Dong CD, Tsai ML, Chen CW, Hung CM (2018) Remediation and cytotoxicity study of polycyclic aromatic hydrocarbon-contaminated marine sediments using synthesized iron oxide-carbon composite. Environ Sci Pollut R 25(1):5243-5253

Ellman GL (1959) Tissue sulfhydryl groups. Arch Biochem Biophys 82(1):70-77

Fan JW, Vankayala R, Chang CL, Chang CH, Chiang CS, Hwang KC (2015) Preparation, cytotoxicity and in vivo bioimaging of highly luminescent water-soluble silicon quantum dots. Nanotechnology 26:21570

Farooq MU, Novosad V, Rozhkova EA, Wali H, Ali A, Fateh AA, Neogi PB, Wang Z (2018) Gold nanoparticles-enabled efficient dual delivery of anticancer therapeutics to HeLa cells. Sci Rep 8:2907

Fernández TD, Pearson JR, Leal MP, Torres MJ, Blanca M, Mayorga C, Le Guével X (2015) Intracellular accumulation and immunological properties of fluorescent gold nanoclusters in human dendritic cells. Biomaterials 43:1-12

Fratoddi I, Venditti I, Cesare Cametti C, Russo MV (2015) The puzzle of toxicity of gold nanoparticles. The case-study of HeLa cells. Toxicol Res 4:796-800

Grabowska-Jadach I, Drozd M, Biegala J, Pietrzak M, MazurkiewiczPawlicka M, Parzuchowski PG, Brzózka Z (2016a) Studies on influence of polymer modifiers for fluorescent nanocrystals' cytotoxicity. J Pharm Biomed Anal 127:193-201

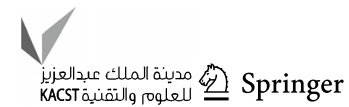


Grabowska-Jadach I, Haczyk M, Drozd M, Fischer A, Pietrzak M, Malinowska E, Brzozka Z (2016b) Evaluation of biological activity of quantum dots in a microsystem. Electrophoresis 37:425-431

Hardman R (2006) A toxicologic review of quantum dots: toxicity depends on physicochemical and environmental factors. Environ Health Perspect 114:165-172

Hassan M, Watari H, AbuAlmaaty A, Ohba Y, Sakuragi N (2014) Apoptosis and molecular targeting therapy in cancer. Biomed Res Int 2014:1-23

He SJ, Cao J, Li YS, Yang JC, Zhou M, Qu CY, Zhang Y, Shen F, Chen Y, Li MM, Xu LM (2016) CdSe/ZnS quantum dots induce photodynamic effects and cytotoxicity in pancreatic cancer cells. World J Gastroenterol 22:5012-5022

Huy BT, Phuong NTK, Nguyen TTT, Lee YI (2018) Photoluminescence spectroscopy of Cd-based quantum dots for optosensing biochemical molecules. Appl Spectrosc Rev 53:313-332

Javanbakht S, Namazi H (2018) Doxorubicin loaded carboxymethyl cellulose/graphene quantum dot nanocomposite hydrogel films as a potential anticancer drug delivery system. Mater Sci Eng C 87:50-59

Karakoti AS, Shukla R, Shanker R, Singh S (2015) Surface functionalization of quantum dots for biological applications. Adv Coll Interface Sci 215:28-45

Kim SW, Kwak JI, An YJ (2016) Fluorescent approach for visually observing quantum dot uptake in living organisms. Chemosphere 144:1763-1770

Kim H, Beack S, Han S, Shin M, Lee T, Park Y, Kim KS, Yetisen AK, Yun SH, Kwon W, Hahn SK (2018) Multifunctional photonic nanomaterials for diagnostic, therapeutic, and theranostic applications. Adv Mater 30(10): 1701460

Lai L, Jin JC, Xu ZQ, Mei P, Jiang FL, Liu Y (2015) Necrotic cell death induced by the protein-mediated intercellular uptake of CdTe quantum dots. Chemosphere 13:240-249

Liu W, Choi HS, Zimmer JP, Tanaka E, Frangioni JV, Bawendi M (2007) Compact cysteine-coated $\mathrm{CdSe}(\mathrm{ZnCdS})$ quantum dots for in vivo applications. J Am Chem Soc 47:1453

Lovrić J, Bazzi HS, Cuie Y, Fortin GR, Winnik FM, Maysinger D (2005) Differences in subcellular distribution and toxicity of green and red emitting CdTe quantum dots. J Mol Med 83:377-385

Mal J, Nancharaiah YV, van Hullebusch ED, Lens PNL (2016) Metal chalcogenide quantum dots: biotechnological synthesis and applications. RSC Adv 6:41477

Manshian BB, Soenen SJ, Al-Ali A, Brown A, Hondow N, Wills J, Jenkins GJ, Doak SH (2015) Cell type-dependent changes in $\mathrm{CdSe} / \mathrm{ZnS}$ quantum dot uptake and toxic endpoints. Toxicol Sci 144:246-258

Medintz IL, Uyeda HT, Goldman ER ER and Mattoussi H (2005) Quantum dots biocoiugates for imaging, labeling and sensing. Nat Mater 4:435-446

Michalet X, Pinaud FF, Bentolila LA, Tsay JM, Doose S, Li JJ, Sundaresan G, Wu AM, Gambhir SS, Weiss S (2005) Quantum dots for live cells, in vivo imaging, and diagnostics. Science 307:538-544

Ni X, Jia S, Duan X, Ding D, Li K (2018) Fluorescent nanoparticles for noninvasive stem cell tracking in regenerative medicine. J Biomed Nanobiotechnol 14(2):240-256

Nikoletopoulou V, Markaki M, Palikaras K, Tavernarakis N (2013) Crosstalk between apoptosis, necrosis and autophagy. Biochem Biophys Acta 1833:3448-3459

Niu Y, Stadler FJ, He T, Zhang X, Yu Y, Chen S (2017) Smart multifunctional polyurethane microcapsules for the quick release of anticancer drugs in BGC 823 and HeLa tumor cells. J Mater Chem B 5(48):9477-9481

Peuschel H, Ruckelshausen T, Kiefer S, Silina Y, Kraegeloh A (2016) Penetration of $\mathrm{CdSe} / \mathrm{ZnS}$ quantum dots into differentiated vs undifferentiated Caco-2 cells. J Nanobiotechnol 14:1477-3155
Pietkiewicz S, Schmidt JH, Lavrik IN (2015) Quantification of apoptosis and necroptosis at the single cell level by a combination of imaging flow cytometry with classical annexin V/propidium iodide staining. J Immunol Methods 423:99-103

Pu Y, Cai F, Wang D, Wang JX, Chen JF (2018) Colloidal synthesis of semiconductor quantum dots toward largescale production: a review. Ind Eng Chem Res 57:1790 - 1802

Ramalingam V, Varunkumar K, Ravikumar V, Rajaram R (2018) Target delivery of doxorubicin tethered with PVP stabilized gold nanoparticles for effective treatment of lung cancer. Sci Rep 8:3815

Ranjbar-Navazi Z, Eskandani M, Johari-Ahar M, Nemati A, Akbari H, Davaran S, Omidi Y (2018) Doxorubicin-conjugated D-glucosamine- and folate-bi-functionalised InP/ZnS quantum dots for cancer cells imaging and therapy. J Drug Target 26(3):267-277

Rello-Varona S, Herrero-Martín D, López-Alemany R, MuñozPinedo C, Tirado OM (2015) Not) all (dead) things share the same breath: identification of cell death mechanisms in anticancer therapy. Can Res 75:913-917

Rocha TL, Gomes T, Durigon EG, Bebianno MJ (2016) Subcellular partitioning kinetics, metallothionein response and oxidative damage in the marine mussel Mytilus galloprovincialis exposed to cadmium-based quantum dots. Sci Total Environ 554:130-141

Sangeetha A, Lakkireddy S, Jamil K, Kapley A, Swamy AVN, Lakkireddy HR (2015) Biophysical, biopharmaceutical and toxicological significance of biomedical nanoparticles. RSC Adv $5: 47830-47859$

Shiohara A, Hoshino A, Hanaki K, Suzuki K, Yamamoto K (2004) On the cyto-toxicity caused by quantum dots. Microbiol Immunol 48:669-675

Silva AC, Freschi AP, Rodrigues CM, Matias BF, Maia LP, Goulart LR, Dantas NO (2016) Biological analysis and imaging applications of $\mathrm{CdSe} / \mathrm{CdS}_{x} \mathrm{Se}_{1-x} / \mathrm{CdS}$ core-shell magic-sized quantum dot. Nanomed Nanotechno Biol Med 12:1421-1430

Soenen SJ, Manshian BB, Aubert T, Himmelreich U, Demeester J, De Smedt SC, Hens Z, Braeckmans K (2014) Cytotoxicity of cadmium-free quantum dots and their use in cell bioimaging. Chem Res Toxicol 27:1050-1059

Subila KB, Kishore Kumar G, Shivaprasad SM, George Thomas K (2013) Luminescence properties of CdSe quantum dots: role of crystal structure and surface composition. J Phys Chem Lett 4:2774 - 2779

Tabei Y, Sonoda A, Nakajima Y, Biju V, Makita Y, Yoshida Y, Horie $M$ (2015) In vitro evaluation of the cellular effect of indium tin oxide nanoparticles using the human lung adenocarcinoma A549 cells. Metallomics 7:816-827

Tamang S, Beaune G, Poillot C, De Waard M, Texier-Nogues I, Reiss P (2011) Compact and highly stable quantum dots through optimized aqueous phase transfer. In: Proceedings of SPIE 7909:79091B

Tram DTN, Wang H, Sugiarto S, Li T, Ang WH, Lee Ch, Pastorin G (2016) Advances in nanomaterials and their applications in point of care (POC) devices for the diagnosis of infectious diseases. Biotechnol Adv 34:1275-1288

Vasudevan D, Gaddam RR, Trinchi A, Cole I (2015) Core-shell quantum dots: properties and applications. J Alloy Compd 636:395-404

Vu TQ, Lam WY, Hatch EW, Lidke DS (2015) Quantum dots for quantitative imaging: from single molecules to tissue. Cell Tissue Res 360:71-86

Wesselborg S, Engels IH, Rossmann E, Los M, Schulze-Osthoff K (1999) Anticancer drugs induce caspase-8/FLICE activation and apoptosis in the absence of CD95 receptor/ligand interaction. Blood 93:3053-3063 
Xu G, Zeng S, Zhang B, Swihart MT, Yong KT, Prasad PN (2016) New generation cadmium-free quantum dots for biophotonics and nanomedicine. Chem Rev 116:12234-12327

Yan M, Zhang Y, Qin H, Liu K, Guo M, Ge Y, Xu M, Sun Y, Zheng $X$ (2016) Cytotoxicity of CdTe quantum dots in human umbilical vein endothelial cells: the involvement of cellular uptake and induction of pro-apoptotic endoplasmic reticulum stress. Int $\mathbf{J}$ Nanomed 11:529-542

Yang Y, Peng J, Zhang X, Ravichandran N, Ying H, Yu C, Ying H, Xu Y, Yin J, Wang K, Wu M, Du Q (2017) New epigallocatechin gallate (EGCG) nanocomplexes co-assembled with 3-mercapto1-hexanol and -lactoglobulin for Improvement of antitumor activity. J Biomed Nanotechnol 13(7):805-814

Yildirimer L, Thanh NT, Loizidou M, Seifalian AM (2011) Toxicology and clinical potential of nanoparticles. Nano Today 6:585-607
Zhang W, Liang Z (2014) Comparison between annexin V-FITC/PI and Hoechst33342/PI double stainings in the detection of apoptosis by flow cytometry. Chin J Cell Mol Immunol 30:1209-1212

Zhang YB, Chen W, Zhang J, Liu J, Chen GP, Pope C (2007) In vitro and in vivo toxicity of CdTe nanoparticles. J Nanosci Nanotechnol 7:497-503

Zhou J, Yang Y, Zhang, Ch-y (2015) Toward biocompatible semiconductor quantum dots: from biosynthesis and bioconjugation to biomedical application. Chem Rev 115:11669-11717

Publisher's Note Springer Nature remains neutral with regard to jurisdictional claims in published maps and institutional affiliations. 